\title{
Nitrogen doses on soybean growth and Asian rust progress in two cultivars
}

\author{
Juliano Perlin de Ramos*1, Jerônimo Luiz Andriolo², Ricardo Silveiro Balardin², \\ Leandro Nascimento Marques², Pablo Tuzi Serafini², Marlon Tagliapietra Stefanello² \\ 'Federal Institute of Education, Science and Technology Farroupilha, Júlio de Castilhos, Brazil \\ ${ }^{2}$ Federal University of Santa Maria, Santa Maria, Brazil \\ *Corresponding author, e-mail: jperlinderamos@gmail.com
}

\begin{abstract}
The main goal of this study was to analyze the range of effects of nitrogen doses on Asian soybean rust (Phakopsora pachyrhizi Sydow) progress over two soybean (Glycine max Merril) cultivars. Two experiments were carried out in greenhouse and in the field, during the 2011/12 and 2012/13 crop years. In the greenhouse, plants were grown in sand in 2011/12 and in a mix of sand and soil in 2012/2013, and supplied with five $N$ doses by dripping fertigation. In the field, the crop was fertilized with six nitrogen doses with broadcast applications. The pathogen was inoculated in all experiments. It was assessed the Area Under Rust Progress Curve (AURPC), defoliation, dry matter, total concentration of $\mathrm{N}$ in leaves, number of grains per plant, thousand grain weight and yield. In the greenhouse experiment, nitrogen rates increased the plant growth and the disease progress during the first year. In 2011/12 field assay, a slight decrease of rust progress and a slight increase in yield from 160 to $242 \mathrm{~kg} \mathrm{ha}^{-1}$ were recorded. However, under favorable environmental conditions for Asian soybean rust, the increases in grain yield obtained by using high $\mathrm{N}$ rates on both cultivars were minor than the damage caused by the disease.
\end{abstract}

Key-words: Glycine max, mineral nitrogen, mineral nutrition, Phakopsora pachyrhizi

\section{Doses de nitrogênio no crescimento da soja e progresso de ferrugem asiática em duas cultivares}

\section{Resumo}

O objetivo principal deste trabalho foi avaliar o efeito de cinco doses de nitrogênio sobre o progresso da ferrugem asiática (Phakopsora pachyrhizi Sydow) em cultivares de soja (Glycine max Merril). Dois experimentos foram conduzidos em casa de vegetação e no campo, nas safras 2011/12 e 2012/13. Na casa de vegetação as plantas foram cultivadas em areia no ano de 2011/12 e uma mistura de areia e solo no período de 2012/13. No campo, as plantas foram submetidas a seis doses de nitrogênio aplicadas em cobertura. O patógeno foi inoculado em todos os experimentos. Determinou-se Área Abaixo da Curva de Progresso da Doença (AACPF), desfolha, massa seca de folhas, concentração total de $\mathrm{N}$ nas folhas, número de grãos por planta, peso de mil grãos e produtividade. Na casa de vegetação, as doses de nitrogênio aumentaram o crescimento de plantas e o progresso da doença no primeiro ano. Em 2011/12 no experimento de campo, um ligeiro decréscimo no progresso da ferrugem e um aumento no rendimento de 160 a $242 \mathrm{~kg} \mathrm{ha}^{-1}$ foram registrados. No entanto, com as condições ambientais favoráveis para a ferrugem asiática da soja, o aumento na produção de grãos pelo uso de altas doses de $\mathrm{N}$ foi comprometido pelos danos causados pela doença, em ambas as cultivares.

Palavras-chave: Glycine max, nutrição mineral, nitrogênio mineral Phakopsora pachyrhizi 


\section{Introduction}

The mineral nutrition is crucial for plant development, limiting the crop production (Fageria, 1998). In soybean (Glycine max Merril), positive responses to development and yield have been documented for fertilization (Corrêa et al., 2004; Gonçalves Junior et al., 2010). The Nitrogen $(N)$ is the most required nutrient by soybean. Prado et al. (2010) reported that soybean plants submitted to $\mathrm{N}$ deficiency decreased the development of organs and shoots, besides yellowing leaves. Furthermore, the $\mathrm{N}$ availability can affect the protein and lipid content in the grains (Ray et al., 2006).

In Brazil, $85 \%$ of total $\mathrm{N}$ on soybean crop is provided by symbiosis between soybean and Bradyrhizobium spp. (Hungria et al., 2006). However, the development of new varieties with high yield potential might suggest the need of new nitrogen sources. Studies have shown positive response on soybean yield to mineral $\mathrm{N}$ application (Ray et al., 2006; Mendes et al., 2008; Nogueira et al., 2010; Petter et al., 2012). Meanwhile, other studies showed no significant response (Barker \& Sawyer, 2005; Hungria et al., 2006; Aratani et al., 2008). Salvagiotti et al. (2008) documented the controversy about $\mathrm{N}$ and soybean yield, suggesting that it was still poorly studied.

The plant nutrition plays an important role to minimize the damage caused by rust in soybean. According to Balardin et al. (2006), nutrient deficiency or excess can increase defenses or promote infections. Soybean rust (Phakopsora pachyrhizi Sydow.) is the main disease in Brazilian soybean production. This disease can occur in all soybean stages, high humidity, mild temperatures and often rainfall are associated to the disease outcome (Tsukahara et al., 2008; Del Ponte et al., 2006). The disease is very aggressive (Yorinori et al., 2005), and in high epidemic situation it may cause losses up to $89 \%$ (Godoy et al., 2009).

Several studies have recorded the effects of crop nutrition on rust development (Balardin et al., 2006; Debona et al., 2008; Pinheiro et al., 201 1; Doreto et al., 2012). Walters \& Bingham. (2007) affirm that different $\mathrm{N}$ sources can affect diseases development in several ways. However, even though nutritional management is recognized as a way to enhance disease control, progress must still be made on this area of study.

The effect of nitrogen doses on progress of Asian soybean rust were the main goal of this research.

\section{Material and Methods}

The study was carried out at the experimental station of Instituto Phytus in Itaara, RS, Brazil (latitude $29^{\circ} 35^{\prime} \mathrm{S}$, longitude $53^{\circ} 48^{\prime} \mathrm{W}$, and $444 \mathrm{~m}$ high). Four experiments were set up in greenhouse and field conditions, from October to March during two following crop years: 2011/12 (Experiments 1 and 2) and 2012/13 (Experiments 3 and 4).

The two chosen cultivars BMX Energia ${ }^{\circledR}$ RR and The BMX Potência ${ }^{\circledR}$ RR are characterized as maturity group 5.0 and 6.7, respectively (BRASMAX, 2014). Both cultivars require medium to high soil fertility and presents low tolerance to biotic and abiotic stresses. Seeds were previously treated with Fipronil (0.25 $\mathrm{g}$ a. i. $\mathrm{kg}^{-1}$ of seeds) and Metalaxil-M + Fludioxonil $\left(0.04 \mathrm{~g}+0.1 \mathrm{~g}\right.$ a. i. $\mathrm{kg}^{-1}$ of seeds). Three hours prior the sowing, it was done an inoculation of Bradyrhizobium japonicum (Bioagro ${ }^{\circledR}$ ) at the dosage of $300 \mathrm{~mL} 50 \mathrm{~kg}^{-1}$ of seeds.

The experiment 1 was set up during $2011 / 12$ growing season. In the greenhouse five raised beds for drip fertigation were built in a closed system for each $\mathrm{N}$ rate. Polypropylene pots (4 $\mathrm{dm}^{3}$ volume) were placed on devices with a basaltic gravel layer in the bottom in order to drain the solution. The pots were filled with washed sand, and arranged in $30 \mathrm{~cm}$ row spacing and $5 \mathrm{~cm}$ between pots.

The fertilizers salt quantities were calculated and the nutrients added to the solution. There were five different nitrogen concentrations in nutrient solutions, with the ratio given in mmol L-1: 5.5 (T1), 8.0 (T2), 10.5 (T3), 13.0 (T4), and 15.5 (T5). The experimental design was completely randomized split-plot $(5 \times 2)$ with four replications, totalizing 40 pots per each treatment. The main factor was five $\mathrm{N}$ doses (main plot) and the secondary factor was the two soybean cultivars (split-plot).

Concentrations of other nutrients were 
kept the same for all treatments, by checking twice a week the electrical conductivity (EC) and $\mathrm{pH}$ of the solutions contained in the tanks. The $\mathrm{EC}$ and $\mathrm{pH}$ of initial solutions were recorded and ranged from 0.9 to $1.2 \mathrm{mS}$ and 5.5 to 5.8 , respectively. When EC showed a deviation greater than $10 \%$, it was adjusted adding water or a new nutrient solution. The $\mathrm{pH}$ was kept in the range of 5.5 to 6.5 by addition of $\mathrm{NaOH}$ or $\mathrm{H}_{2} \mathrm{SO}_{4}$ in the concentration of $1 \mathrm{~N}$. The solution was completely renewed whenever the level reached $30 \%$ of the tank content.

The nutrient solution was automatically pumped into the pots four times a day, during 15 minutes and controlled by a timer. The excess of solution was drained through the rails installed in the lower side of the raised bed, which led nutrient solution to the $500 \mathrm{dm}^{3}$ tanks located under the benches.

The experiment 2 was carried out in the field. The soil was classified as sandy with $286 \mathrm{~g}$ $\mathrm{kg}^{-1}$ of sand, $470 \mathrm{~g} \mathrm{~kg}^{-1}$ of silt, and $244 \mathrm{~g} \mathrm{~kg}^{-1}$ of clay, belonging to the Franco class (EMBRAPA, 2013). The soil $\mathrm{pH}$ was 5.6, with organic matter $\left(27 \mathrm{~g} \mathrm{~kg}^{-1}\right)$, phosphorus (20.8 $\left.\mathrm{mg} \mathrm{dm}^{-3}\right)$, potassium $\left(160 \mathrm{mg} \mathrm{dm}^{-3}\right)$, calcium $\left(5.3 \mathrm{cmol} \mathrm{dm}^{-3}\right), \mathrm{Mg}$ $\left(\mathrm{cmol} \mathrm{dm}{ }^{3}\right)$ and CEC $\left(11.2 \mathrm{cmol} 5.3 \mathrm{dm}^{-3}\right)$ contents. Meteorological data were collected from a meteorological station located at the experimental field (Table 1).

Table 1. Averages of temperatures and rainfall at the experimental site during the crop growing periods in 201 1/2012 and 2012/2013. Itaara - Rio Grande do Sul, Brazil.

\begin{tabular}{cccccccccc}
\hline Year & Month & \multicolumn{2}{c}{ Min $\left(\mathrm{C}^{\circ}\right)$} & \multicolumn{3}{c}{$\operatorname{Max}\left(\mathrm{C}^{\circ}\right)$} & \multicolumn{2}{c}{$\operatorname{Med}\left(\mathrm{C}^{\circ}\right)$} & \multicolumn{2}{c}{ Rainfall $(\mathrm{mm})$} \\
\hline $2011(2012)$ & October & 13.52 & $(15.26)$ & 22.51 & $(23.63)$ & 18.01 & $(19.45)$ & 177 & $(294)$ \\
$2011(2012)$ & November & 15.28 & $(20.64)$ & 26.29 & $(26.81)$ & 20.78 & $(23.72)$ & 28 & $(79)$ \\
$2011(2012)$ & December & 16.33 & $(19.60)$ & 27.66 & $(30.20)$ & 22.00 & $(24.90)$ & 40 & $(329)$ \\
$2012(2013)$ & January & 18.23 & $(18.01)$ & 29.84 & $(29.92)$ & 24.04 & $(23.97)$ & 98 & $(152)$ \\
$2012(2013)$ & February & 20.50 & $(18.44)$ & 30.64 & $(27.48)$ & 25.57 & $(22.96)$ & 294 & $(102)$ \\
$2012(2013)$ & March & 11.90 & $(15.64)$ & 26.40 & $(24.14)$ & 19.15 & $(19.89)$ & 34 & $(219)$ \\
\hline In parentheses: first experiment year Without parentheses: second experiment. & & & & & &
\end{tabular}

Soybean was sown in November $19^{\text {th }}$, sowing 14 seeds per meter and with $0.5 \mathrm{~m}$ row spacing, supported by a precision seederfertilizer. The P-K were applied at the rates of 168 $\left(\mathrm{P}_{2} \mathrm{O}_{5}\right)$ and $120\left(\mathrm{~K}_{2} \mathrm{O}\right) \mathrm{kg} \mathrm{ha}^{-1}$. The experiment was a factorial randomized block design with split plots $(2 \times 6)$ with four replications. The two cultivars composed the main plots and split-plot with six $\mathrm{N}$ doses $\left(0,30,60,120,180\right.$ and $\left.240 \mathrm{~kg} \mathrm{ha}^{-1}\right)$ always in three applications $\mathrm{V} 3, \mathrm{~V} 5$ and $\mathrm{R} 1$ stages. Using urea as source of $N$. The plots were ( $3 \times 5$ meters) covering 6 soybean rows. When it needed, the experiment was irrigated. The management of pests and weeds were done according to the good field practices.

The experiment 3 was established in the greenhouse during the 2012/13 crop year. The pots were filled with substrate composed by washed sand and soil (1:2) from the same site in the field. It was kept the same level of P-K added at sowing in the field, considering the application of fertilizer in a proportional soil profile of 0-10 $\mathrm{cm}\left(1 \mathrm{~m}^{2}=100 \mathrm{dm}^{3}\right)$, in order to provide similar nutrient availability in both field and greenhouse experiment following the same rule to the $\mathrm{N}$ plots treatments. Applying the total nutrient doses in the substrate preparation. The $\mathrm{N}$ concentrations were $0,30,60,120,180$ and $240\left(\mathrm{mg} \mathrm{dm}^{-3}\right)$. The drip fertigation was made with the same frequency of the Experiment 1.

The experiment 4 was a replication of the experiment 2. It was conducted in the same field, from November $4^{\text {th }}, 2012$ to March, 2013. Nonetheless, irrigation was not necessary due to a good availability of water provided by rainfall at the period.

At Rl stage, for all experiments, the soybean plants were inoculated using $P$. pachyrhizi spore suspension. The suspension was obtained by adding $10 \mathrm{~mL}$ of tween (1\%) per liter of the pathogen spore suspension, at $1 \times 10^{6} \mathrm{~mL}^{-1}$ concentration, determined with the assistance of the Newbaver chamber. The spores were directly collected from infected soybean plants. Inoculation was performed using a $\mathrm{CO}_{2}$ pressurized bar with four nozzles XR 11001. The rate applied was $150 \mathrm{~L} \mathrm{ha}^{-1}$ at 33 psi of pressure. Afterwards 150 pots containing infected soybean plants by $P$. pachyrhizi were put into a greenhouse, in order to simulate natural and 
constant inoculation.

It was evaluated the severity of Asian soybean rust and subsequently calculated the Area Under Rust Progress Curve (AURPC), defoliation (\%), thousand grain weight (TGW), grain yield per plant and yield in both greenhouse and field. Nitrogen content $\left(\mathrm{g} \mathrm{kg}^{-1}\right)(\mathrm{NCL})$, leaves dry matter (g) (DML) at R1 stage and number of grains per plant (GP) were obtained from the greenhouse experiments.

The AURPC was calculated using the equation proposed by (Campbell \& Madden, 1990) using severity data from four weekly assessments. Starting 10 days after the inoculation and based on diagrammatic scale suggested by (Godoy et al., 2006). The assessments considered the same four plants per treatment at the greenhouse, and four randomized points in the middle of each plot in the field, considering only the middle part of the canopy. Defoliation was estimated counting the number of nodes in the main stem with and without leaves at the very moment and sampled in the date of each severity evaluation.

For DML and NCL determinations, four plants per treatment were collected in the greenhouse and field experiments. The leaves were taken off, bagged and then dried. The leaves weight was gotten on analytical scale. Afterwards leaves were sent to the Forest Ecology Laboratory at the Federal University of Santa Maria to determine $\mathrm{N}$ content in leaves, using the Kjeldahl method.

After maturation (R9), four plants were harvested from greenhouse experiments, being each plant a replication. In the field eight square meters were combined, yield, and thousand grain weight were determined based on moisture content of $13 \%$. The grain number per plant (GP) was counted using the Auto Meter grain.

Statistical analysis were performed running the spreadsheet in Office Excel, Sigma Plot software and Assistat 7.7. The F test ( $\mathrm{p}$-value $<0.05$ ) was used for testing the main effects and interactions between $\mathrm{N}$ rates and cultivars. When interactions or $\mathrm{N}$ rates effects were significant, data were submitted to regression analysis. The matrix of linear simple correlation with the coefficients between assessed variables was estimated by the ( $\mathrm{p}$-value $<0.05$ ) significance and ( $p$-value $<0.01)+$ test, in greenhouse experiments.

\section{Results}

The $\mathrm{N}$ availability did not show any effect on nitrogen content in leaves (NCL) as observed in 2011/12 and 2012/13 experiments (Figures $1 \mathrm{E}, \mathrm{F}$ ). The area under rust progress curve (AURPC) increased three times on both cultivars considering the increase of free $N$ in the 2011/12 greenhouse experiment (Figure 1 A). Nonetheless, a slight reduction on the area under disease progress can be seen on both cultivars for the 2012/2013 experiment (Figure 1 B). Defoliation showed similar trends of the AURPC. In these experiments the increase of $\mathrm{N}$ availability resulted on an average defoliation of $25 \%$ on both cultivars in 2011/12 (Figures 1 C), this defoliation was likely caused by the increase of the rust progress rate.

BMX Energia ${ }^{\circledR}$ showed a good response on GP for rates up to $10.5 \mathrm{mmol} \mathrm{L}^{-1}$, while $\mathrm{BMX}$ Potência ${ }^{\circledR}$ had a decrease on this parameter in 2011/12 (Figure $2 \mathrm{C}$ ). The cultivars average demonstrated a gain on GP in 2012/13. The TGW only showed significant interaction between $\mathrm{N}$ and cultivars in 2011/2012. Decreases on TGW were noticed for $\mathrm{N}$ concentration above 10.5 $\mathrm{mmoL}^{-1}$ on $\mathrm{BMX}$ Energia ${ }^{\circledR}$ (Figure $2 \mathrm{E}$ ). While BMX Potência ${ }^{\circledR}$ showed an increase of 50 grams from 5.5 to $10.5 \mathrm{mmol} \mathrm{L}^{-1}$.

The interaction between nitrogen rates and cultivars did not show significance for DML in $\mathrm{R} 1$ stage in 2011 / 12, GP in 2012/13, TGW in 2012/13 and yield per plant in 2012/13 (Figure $2 \mathrm{~A}, \mathrm{D}, \mathrm{FH}$ ). The DML increased 50\% in 2011/12 (Figure $2 \mathrm{~A}$ ) and $B M X$ Energia ${ }^{\circledR}$ resulted in significant decrease on DML for nitrogen concentration above 120 $\mathrm{mg} \mathrm{dm}^{-3}$ in 2012/13 (Figure $2 \mathrm{~B}$ ), although there was no difference on DML for BMX Potência ${ }^{\circledR}$. No difference on TGW was recorded in the 2012/13 experiment (Figure 2 F). The BMX Energia ${ }^{\circledR}$ had lower yield under high $\mathrm{N}$ availability. On the other hand, the BMX Potência ${ }^{\circledR}$ increased the yield from 30 to 40 grams per plant on the first year (Figure $2 \mathrm{G}$ ). 
$2011 / 12$
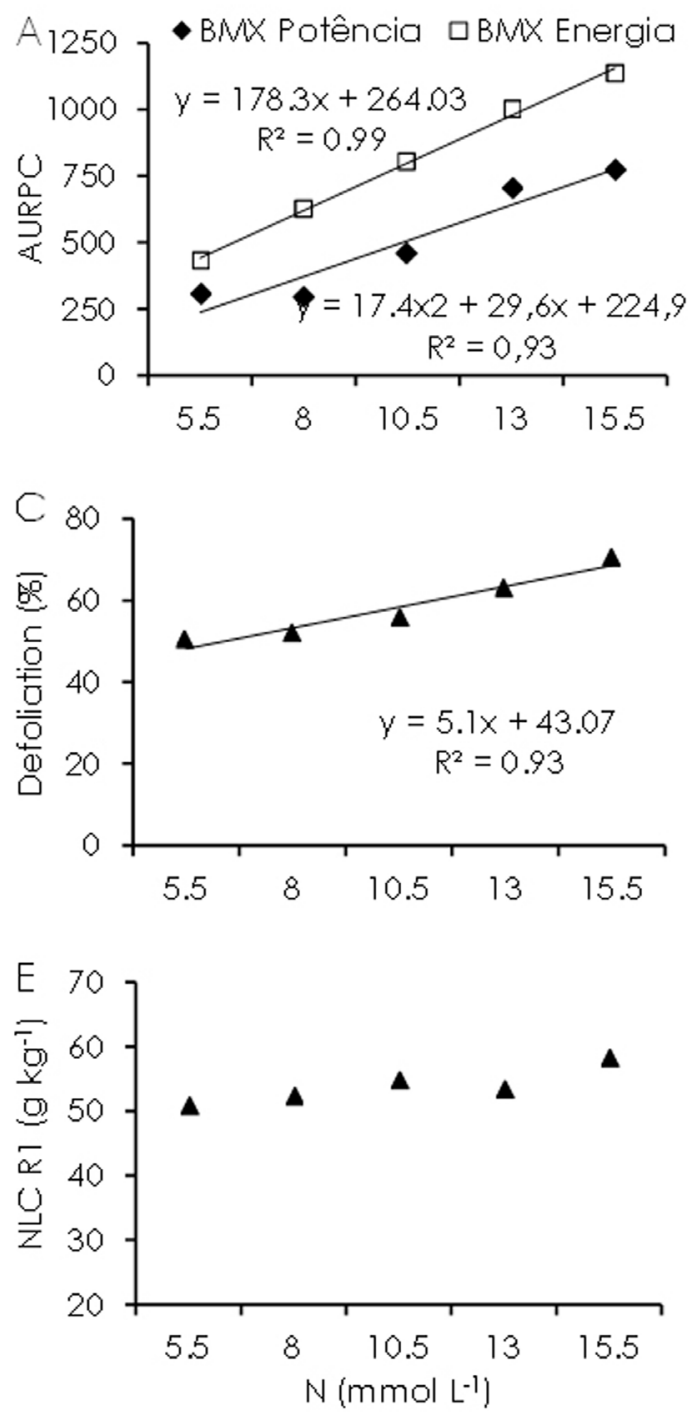

$2012 / 13$
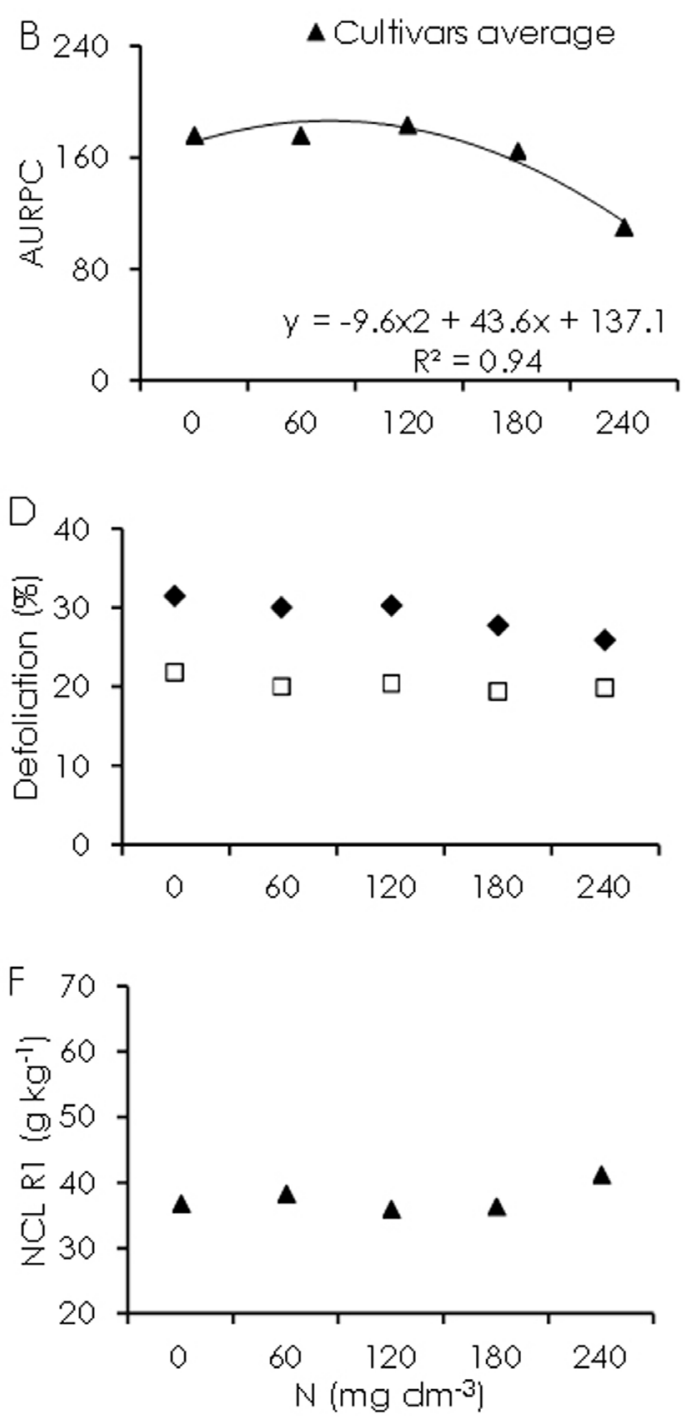

Figure 1. Area under rust progress curve (AURPC) (A, B), defoliation (C, D), nitrogen leaves concentration (NLC) (E, F) at R1 Stage grown on sand with $N$ concentrations of 5.5, 8.0, 10.5, 13.0, and $15.5 \mathrm{mmol} \mathrm{L}^{-1}$ (A, C, E) (Experiment 1, 201 1/12) and grown in sandy soil with lower concentrations of $0,60,120,180$ and $240 \mathrm{mg} \mathrm{kg}^{-1}$ (B, D, F) (Experiment 2, 2012/13). 

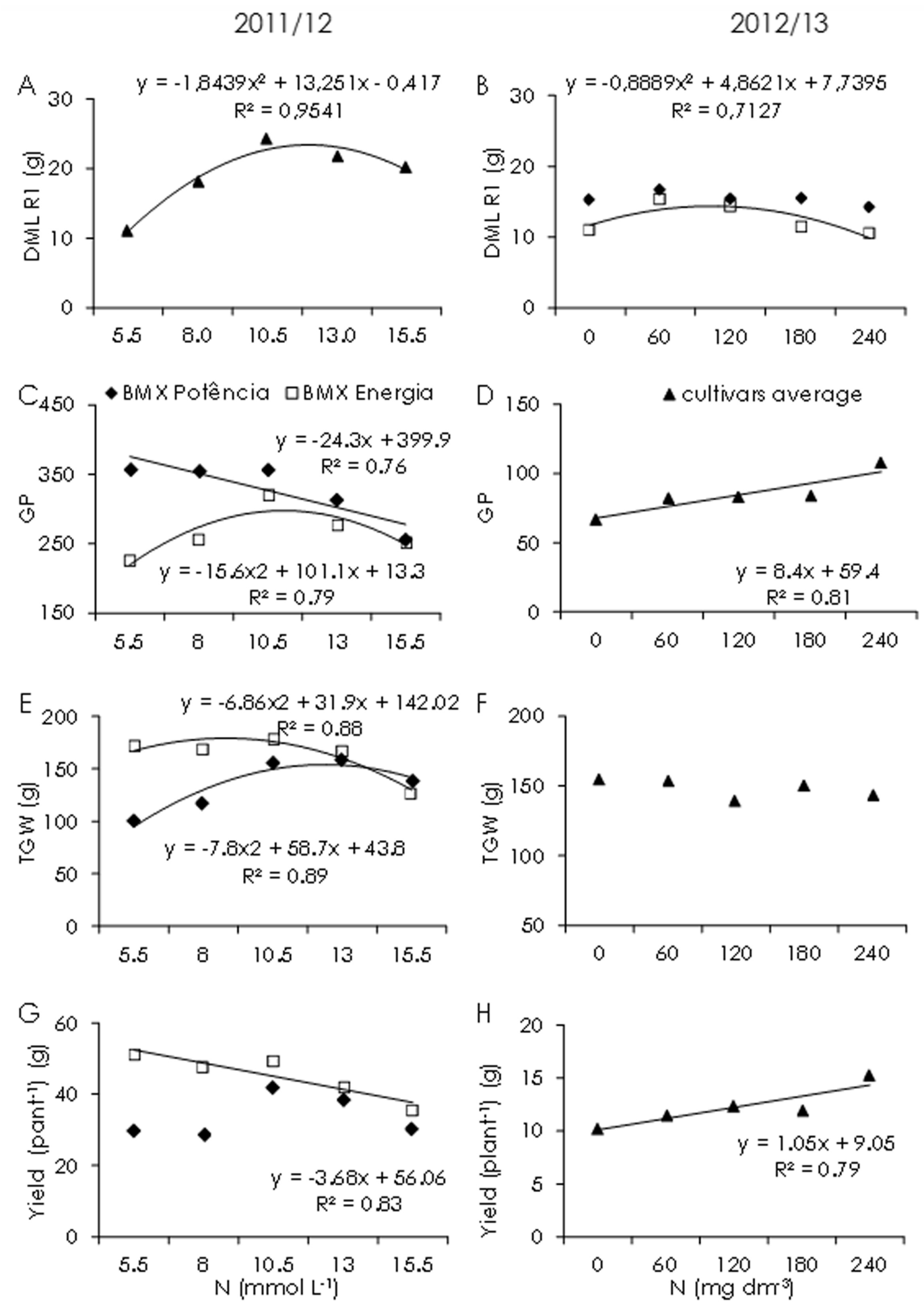

Figure 2. Dry matter of leaves (DML) (A, B) at Rl Stage. Grains per plant (GP) (C, D), thousand grain weight (TGW) (E, F), (Yield plant $\left.{ }^{-1}\right)(G, H)$ grown on sand with $N$ concentrations of $5.5,8.0,10.5,13.0$ and $15.5 \mathrm{mmol} \mathrm{L}^{-1}(\mathrm{~A}, \mathrm{C}, \mathrm{E})(2011 / 12)$ and in sand plus soil with $\mathrm{N}$ rates of $0,60,120,180$ and $240 \mathrm{mg} \mathrm{dm}^{-3}$ (B, D, F) (2012/13).

Field data in 2011/12 (Figure 3) showed a reduction on AURPC for high $\mathrm{N}$ rates, supporting the second year greenhouse experiment. However, it contrasts to the results found in the first greenhouse experiment. Yield responded quite well in the first year for the $\mathrm{N}$ application.
Meanwhile, there was no significance response in the following year for any of the studied parameters (Figures $3 \mathrm{~B}, \mathrm{D}, \mathrm{F}, \mathrm{H}$ ).

The interaction between $\mathrm{N}$ doses and cultivars were significant for AURPC, defoliation and yield. The AURPC and defoliation showed 
linear decrease on both cultivars (Figure $3 \mathrm{~A}, \mathrm{C}$ ). No significant interaction between $\mathrm{N}$ doses and cultivars was observed on TGW in 2011 / 12, neither effect due to $\mathrm{N}$ rates in 2012/13 experiments (Figure 3 E, F). In 2011/12, there was a linear increase of $162 \mathrm{~kg} \mathrm{ha}^{-1}$, from 0 to $240 \mathrm{~kg}$ of $\mathrm{N} \mathrm{ha}^{-1}$ on yield (Figure $3 \mathrm{G}$ ) of BMX Energia ${ }^{\circledR}$ and up to $242 \mathrm{~kg} \mathrm{ha}^{-1}$ BMX Potencia ${ }^{\circledR}$. Nonetheless, the yield gain with the higher $\mathrm{N}$ rates on both cultivars were minor than the damage caused by the disease.
$2011 / 12$
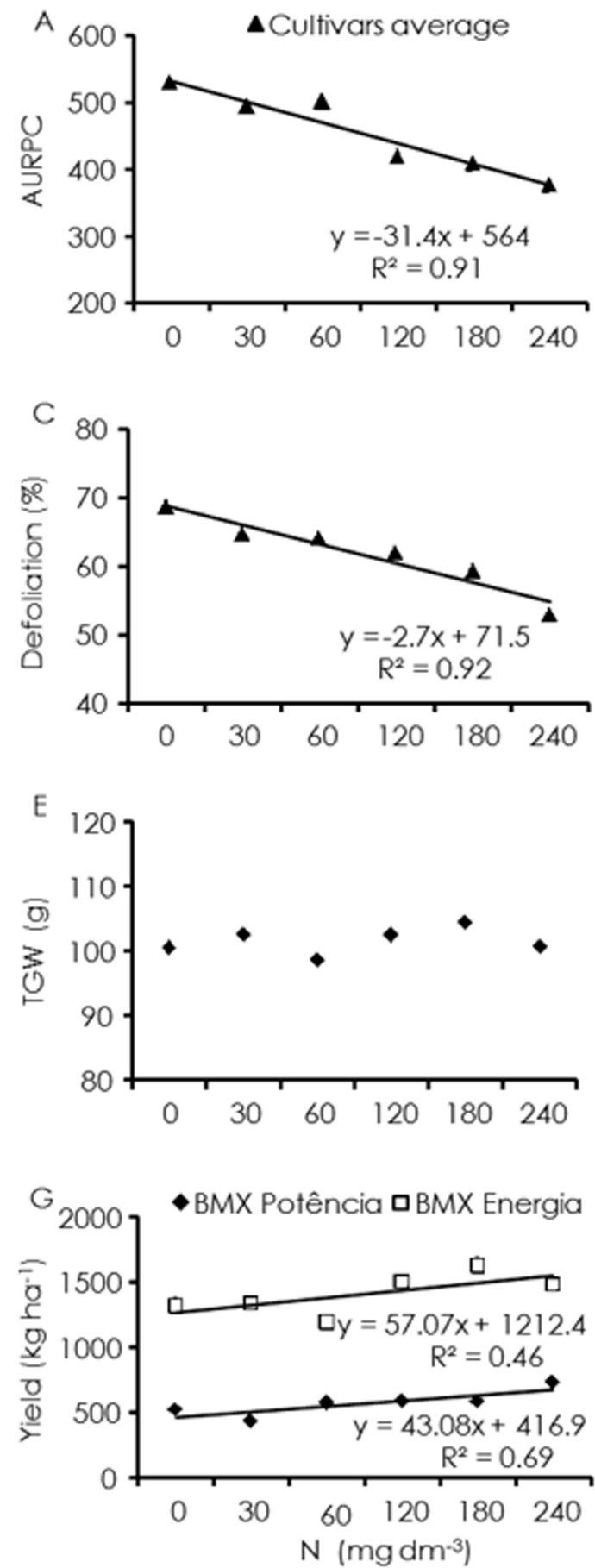

$2012 / 13$
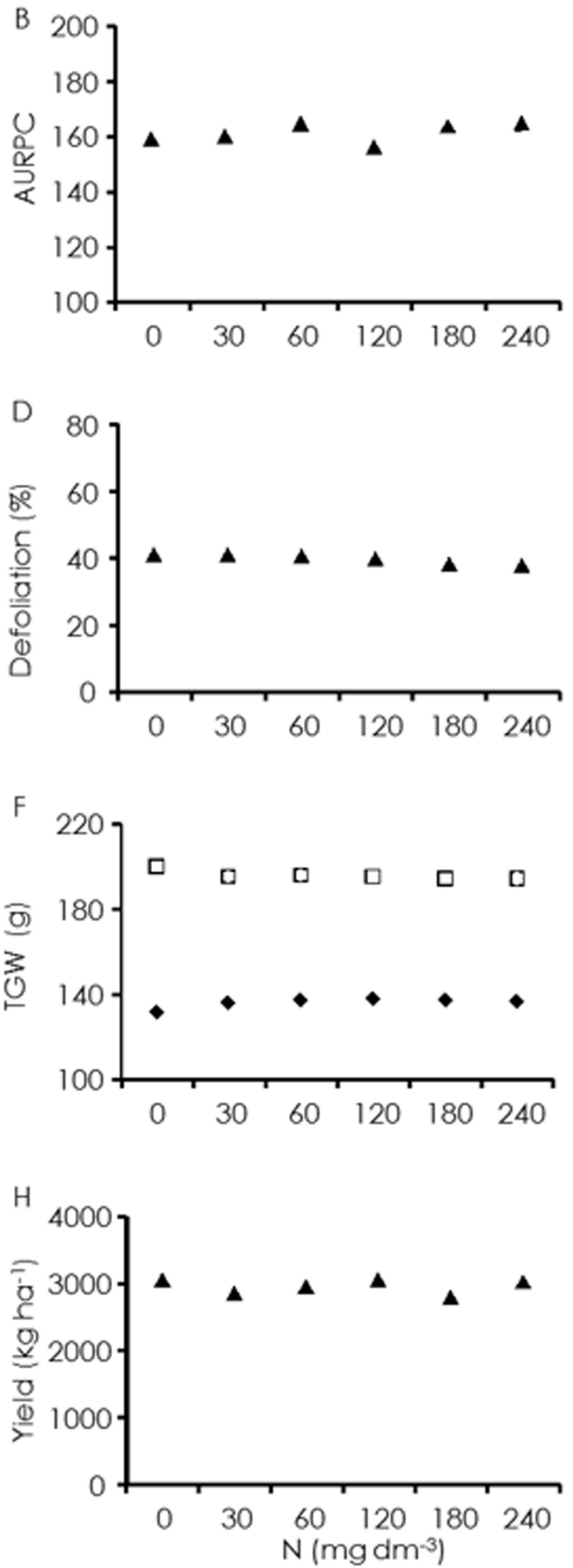

Figure 3. Area under rust progress curve (AURPC) (A, B), defoliation (C, D), thousand grain weight (TGW) (E, F), yield (G, $\mathrm{H}$ ) grown in tillage with the $\mathrm{N}$ doses of $0,60,120,180$ and $240 \mathrm{~kg} \mathrm{ha}^{-1}$ in 2011/12 (Experiment 2; $\mathrm{A}, \mathrm{C}, \mathrm{E}, \mathrm{G}$ ) and 2012/13 (Experiment 4; B, D, F, H). 


\section{Discussion}

Analyzing the data from Experiments 1 and 3 , there are two factors that can explain the variation in the progress of rust. First, increasing the rate of $\mathrm{N}$ into nutrient solution resulted in a bigger DML, with a large leaf area. Besides nitrogen is bonded on photosynthetic apparatus, increasing its availability results in more biomass, leading to canopy microclimate conditions more favorable to the appearance of rust (Nogueira et al., 2010; Nunes-Nesi et al., 2010; Lima et al., 2012).

Furthermore, soybean plants under shady conditions encouraged rust development (Debona et al., 2008). According to Furtado et al. (2009) the presence of light drastically reduces the germination of $P$. phakyrhizi spores. This information suggests that the excessive soybean growth can speed up the soybean rust progress.
Thus, the optimal biomass must be studied for each variety of soy, avoiding overgrowth and potential problems brought by diseases.

Additionally, despite the NLC did not show any significance, $\mathrm{N}$ availability may cause biochemical changes affecting plant response against pathogens (Snoeijers et al. 2000; Neumann et al. 2004; Planchert and Kaiser, 2006). Indeed, Pinheiro et al. (2011) and Doreto et al. (2012) observed that excessive potassium fertilization increased the rust progress. Meanwhile, when this nutrient was balanced supplied with other nutrients, such as calcium, a reduction on soybean rust was recorded. Balardin et al. (2006) found that balanced availability of phosphorus and potassium decreased the soybean rust severity. Thus, the balance among positive and negative factors defines the supremacy of defense process or increase the epidemic.

Table 2. Simple correlation among variables, Area under rust progress curve (AURPC), defoliation (DEFOL), nitrogen centration in leaves, (NCL), dry mass of leaves (DML), plant height, grains per plant (GP), thousand grain weight (TGW) and yield, in two crop periods of plants grown in the greenhouse with sand (Experiment 1, 2011/12) and in the mixture of sand and soil (Experiment 3, 2012/13)

\begin{tabular}{|c|c|c|c|c|c|c|c|}
\hline \multicolumn{8}{|c|}{ Experiment - 1} \\
\hline VA\VA & AURPC & DEFOL & NLC & $\mathrm{DML}$ & GP & TGW & YIELD \\
\hline AURPC & 1 & $0.92^{* *}$ & $0.44^{*}$ & $0.59 * *$ & $-0.42^{*}$ & $0.23 n s$ & $0.14 \mathrm{~ns}$ \\
\hline DEFOL & - & 1 & $0.41^{*}$ & $0.53^{* *}$ & $-0.59 * *$ & $0.26 \mathrm{~ns}$ & $0.16 \mathrm{~ns}$ \\
\hline NLC & - & - & 1 & $0.10 \mathrm{~ns}$ & -0.18 & $0.02 \mathrm{~ns}$ & $-0.13 n s$ \\
\hline DML & - & - & - & 1 & -0.09 & $0.36 n s$ & $0.18 \mathrm{~ns}$ \\
\hline GP & - & - & - & - & 1 & $-0.30 n s$ & $-0.19 n s$ \\
\hline TGW & - & - & - & - & - & 1 & $0.65^{* *}$ \\
\hline YIELD & - & - & - & - & - & - & 1 \\
\hline \multicolumn{8}{|c|}{ Experiment -3} \\
\hline AURPC & 1 & $-0.54^{*}$ & $-0.53^{*}$ & $-0.23 n s$ & $-0.67^{* *}$ & $-0.25 n s$ & $-0.81^{* *}$ \\
\hline DEFOL & - & 1 & $0.29 \mathrm{~ns}$ & $0.65^{* *}$ & $0.20 \mathrm{~ns}$ & $0.15 \mathrm{~ns}$ & $0.37 \mathrm{~ns}$ \\
\hline NLC & - & - & 1 & $0.22 \mathrm{~ns}$ & $0.33 \mathrm{~ns}$ & $0.16 \mathrm{~ns}$ & $0.37 \mathrm{~ns}$ \\
\hline DML & - & - & - & 1 & $0.10 \mathrm{~ns}$ & $-0.07 n s$ & $0.13 \mathrm{~ns}$ \\
\hline GP & - & - & - & - & 1 & $0.10 \mathrm{~ns}$ & $0.85^{* *}$ \\
\hline TGW & - & - & - & - & - & 1 & $0.24 \mathrm{~ns}$ \\
\hline YIELD & - & - & - & - & - & - & 1 \\
\hline
\end{tabular}

On sand experiment, positive correlations between AURPC and defoliation ( $r 2=0.92), \mathrm{DML}$ and AURPC ( $r 2=0.59$ ), DML and defoliation ( $r 2$ $=0.53), \mathrm{TGW}$ and productivity $(\mathrm{r} 2=0.65)$ were observed. Negative correlations occurred between AURPC and GP ( $\mathrm{r} 2=-0.42)$, defoliation and GP ( $r 2=-0.59)$. In this case, the excess of leaves achieved by increasing $\mathrm{N}$ was lost due to defoliation.

In experiment 3, although the crop was supplied with a complete nutrition solution, the plants were visually smaller than in the previous year. The porosity of the sand and soil mix was lower than pure sand. Thus, it might have resulted on worse condition for root development. The correlation between variables showed some changes (Table 2). Positive correlations were observed for GP and Yield ( $r 2=0.85)$. The negative correlations occurred between AURPC and defoliation ( $r 2=-0.54)$, AURPC and GP (r2 = 0.67), AURPC and Yield ( $r 2=-0.81)$. It should be noticed that several factors add to manage rust 
and achieve high yields, while the $\mathrm{N}$ availability may influence some conditions that benefits the soybean rust development.

The gains in grain yield in the 2011/2012 growing season match the previous data documented by Mendes et al. (2008) and Petter et al. (2012). Yet, the absence of response in the second year supports the studies developed by Hungria et al. (2006) and Aratani et al. (2008) which found no response for mineral $\mathrm{N}$ application and it might be explained by the frequent rainfalls during the period, leaching the $\mathrm{N}$, as it has been reported by Robertson \& Groffman (2007)

Therefore, yield gain and the reduction on soybean rust by increasing the $\mathrm{N}$ availability, should not be seen as an isolated solution against soybean rust. But, further as a useful information of how $\mathrm{N}$ nutrition of soybean plants can help or make difficult the management of soybean rust.

\section{Conclusions}

The increase in nitrogen availability for soybeans, when it is not in excess, may decrease the progress of soybean rust.

This decrease was not related to the concentration of nitrogen in foliage.

When the availability of nitrogen caused an excessive growth, the progress of soybean rust increased and resulted in a bigger damage by this disease.

\section{References}

Aratani, R.G., Lazarini. E., Marques R.R. Brackes. C. 2008. Adubação nitrogenada em soja na implantação do sistema plantio direto. Bioscience Journal 24: 31-38.

Balardin, R.S., Dallagnol, L.J., Didoné H.T., Navarine. L. 2006. Influência do Fósforo e do Potássio na Severidade da Ferrugem da Soja Phakopsora pachyrhizi. Fitopatologia Brasileira 31: 462-467.

Barker, D.W., Sawyer. J.E. 2005. Nitrogen Application to soybean at early reproductive development. Agronomy Journal 97: 615-619.

BRASMAX. http://brasmaxgenetica.com.br/ cultivar/regiao-sul/. < Access in: April 08 ${ }^{\text {th }}, 2014>$.

Campbell, C.L., Madden, L.V. 1990. Introduction to plant disease epidemiology. New York, NY, USA, $532 \mathrm{p}$.
Corrêa, J.C., Mauad, M., Rosolem, C.A. 2004. Fósforo no solo e desenvolvimento de soja influenciados pela adubação fosfatada e cobertura vegetal. Pesquisa Agropecuária Brasileira 39: 1231-1237.

Debona, D., Navarine, L., Favera, D.D., Balardin, R.S. 2008. Efeito de níveis de cálcio e sombreamento em plantas de soja sobre a infecção por Phakopsora pachyrhizi. Tropical Plant Pathology 33: 388-389.

Del Ponte, E.M., Godoy, C.V., Li, X., Yang, X.B. 2006. Predicting Severity of Asian Soybean Rust Epidemics with Empirical Rainfall Models. Phytopathology 96: 797-803.

Doreto, R.B,S., Gavassoni, W.L, Silva, E.F. da, Marchetti, M.E., Bacchi. L.M.A., Stefanello F.F. 2012. Ferrugem asiática e produtividade da soja sob doses de potássio e fungicida, na safra 2007/08. Ciências Agrárias 33: 941-952.

Fageria, N.K. 1998. Otimização da eficiência nutricional na produção das culturas. Revista Brasileira de Engenharia Agrícola e Ambiental 2: 6-16.

Furtado, G.Q., Alves, S.A.M., Godoy, C.V., Salatino, M.L.F., Massola Júnior, N.S. 2009. Influência da luminosidade e da camada de cera epicuticular de superfícies de folhas de soja na infecção de Phakopsora pachyrhizi. Tropical Plant Pathology 34: 306-312.

Godoy, C.V., Koga, L.J., Canteri, M.G. 2006 Diagrammatic scale for assessment of soybean rust severity. Fitopatologia Brasileira 31: 63-68.

Godoy C.V., Flausino A.M., Santos L.C.M., Del Ponte, E.M. 2009. Eficiência do controle da ferrugem asiática da soja em função do momento de aplicação sob condições de epidemia em Londrina, PR. Tropical Plant Pathology 34: 56-61.

Gonçalves Junior, A.C., Nacke, H., Marengoni, N.G., Carvalho, E.A. da, Coelho, G.F. 2010. Produtividade e componentes de rendimento da soja adubada com diferentes doses de fósforo, potássio e zinco. Ciência e Agrotecnologia 34: 660-666.

Hungria, M., Franchini. J.C., Campo, R.J, Crispino, C.C., Moraes, J.Z., Sibaldelli, R.N.R, Mendes IC, Arihara J 2006 Nitrogen nutrition of soybean in Brazil: Contribuitions of biological N2 fixation and $\mathrm{N}$ fertilizer to grain yield. Canadian Journal of Plant Science 86: 927-939.

Lima, S.F., Alvarez, R.C.F., Theodoro, G.F., Bavaresco., M., Silva, K.S. 2012. Efeito da semeadura em linhas cruzadas sobre a produtividade de grãos e a severidade da ferrugem asiática da soja. Bioscience Journal 28: 954-962. 
Mendes, I.C., Reis Junior, F.B. dos, Hungria, M., Sousa, D.M.G. de, Campo, R.J. 2008. Adubação nitrogenada suplementar tardia em soja cultivada em latossolos do cerrado. Pesquisa Agropecuária Brasileira 43: 1053-1060.

Neumann, S. et al. Nitrogen per unit leaf area affects the upper asymptote of Puccinia striiformis f.sp. tritici epidemics in winter wheat. Plant Pathology 53: 725-732, 2004.

Nogueira, P.D.M., Sena Junior, D.G., Ragagnin, V.A. 2010. Clorofila foliar e nodulação em soja adubada com nitrogênio em cobertura. Global Science and Technology 3: 117-124.

Nunes-Nesi, A., Fernie, A.R., Stitt, M .2010. Metabolic and Signaling Aspects Underpinning the Regulation of Plant Carbon Nitrogen Interactions. Molecular Plant 3: 973-996.

Petter, F.A., Pacheco L.P., Neto, F. de A., Santos, G.G. 2012. Respostas de cultivares de soja à adubação nitrogenada tardia em solos de cerrado. Revista Caatinga 25: 67-72.

Pinheiro, J.B., Pozza, E.A., Pozza, A.A.A., Moreira A. de S., Alves, M.C. 2011 . Severidade da ferrugem da soja em função do suprimento de potássio e cálcio em solução nutritiva. Revista Ceres 58: 4350 .

Planchet, E., Kaiser, W.M. 2006. Nitric oxide production in plants. Plant Signaling \& Behavior 1: 46-51.

Prado, R.M., Franco, C.F., Puga, A.P. 2010. Deficiências de macronutrientes em plantas de soja cV. BRSMG 68 Vencedora cultivada em solução nutritiva. Comunicata Scientiae 1: 114119.

Ray, J.D., Fritschi, F.B., Heatherly, L.G. 2006. Large applications of fertilizer $\mathrm{N}$ at planting affects seed protein and oil concentration and yield in the early soybean production system. Field Crops Research 99: 67-74.

Robertson, G.P., Groffman, P.M. 2008. Nitrogen Transformation. In: Paul, E.A. ed. Soil Microbiology, Biochemistry and Ecology. New York, NY, USA. P. 341-364.

Salvagiotti, F., Cassman, K.G., Specht, J.E., Walters, D.T., Weiss, A., Dobermann, A. 2008. Nitrogen uptake, fixation and response to fertilizer $\mathrm{N}$ in soybeans: A review. Field Crops Research 108: 1-13.

Snoeijers, S.S., Pérez-García, A., Joosten, M.H.A.J., De Wit., P.J.G.M. 2000. The effect of nitrogen on development and gene expression in bacterial and fungal plant pathogens. European Journal of Plant Pathology 106: 493-506.
Tsukahara, R.Y., Hikishima, M., Canteri, M.G., 2008. Relações entre clima e o progresso da ferrugem asiática Phakopsora pachyrhizi em duas microrregiões do Estado do Paraná. Ciências Agrárias 29: 47-52.

Walters D.R.; Bingham, I.J. 2007. Influence of nutrition on disease development caused by fungal pathogens: implications for plant disease control. Annals of Applied Biology 151: 307-324.

Yorinori, J.T., Paiva, W.M., Frederick, R.D., Costamilan, L.M., Bertagnolli, P.F., Hartman, G.E., Godoy, C.V., Nunes Junior, J. 2005. Epidemics of soybean rust Phakopsora pachyrhizi in Brazil and Paraguay from 2001 to 2003. Plant Disease 89: 675-677. 